\title{
HUBUNGAN PEMAHAMAN KONSEP ARITMATIKA SOSIAL DENGAN HASIL BELAJAR IPS MATERI PPH
}

\author{
Nurina Kurniasari Rahmawati ${ }^{1}$, Arie Purwa Kusuma ${ }^{2}$ \\ ${ }_{1,2}$ Program Studi Pendidikan Matematika, STKIP Kusuma Negara \\ nurinakr@stkipkusumanegara.ac.id
}

\begin{abstract}
Abstrak
Matematika tidak terlepas dari konsep-konsep yang bersifat abstrak, penguasaan konsep-konsep matematika merupakan prasyarat untuk dapat memahami dan mengembangkan cabang ilmu-ilmu yang lain. Matematika juga memiliki hubungan antara ilmu satu dengan yang lain sehingga dalam setiap memperkenalkan konsep yang baru diperlukan konsep selanjutnya yang lebih tinggi. Sebagai ilmu yang universal, matematika tidak dapat terpisahkan dari berbagai disiplin ilmu lain. Salah satu ilmu atau matapelajaran yang memiliki keterkaitan dengan matematika adalah Ilmu Pengetahuan Sosial (IPS). Penelitian ini bertujuan untuk mengetahui apakah terdapat korelasi positif antara pemahaman konsep aritmatika sosial dengan hasil belajar IPS pada materi PPH. Metode yang digunakan dalam penelitian ini adalah metode deskriptif kuantitatif dengan teknik survey melalui pendekatan korelasi. Populasi yang digunanakan dalam penelitian ini adalah siswa kelas VIII yang berjumlah 30 siswa. Teknik pengumpulan data yang digunakan adalah dengan tes berbentuk pilihan ganda sebanyak 30 butir soal. Teknik analisis data yang digunakan untuk menguji hipotesis adalah teknik korelasi product moment. Hasil penelitian ini menunjukkan bahwa terdapat hubungan yang signifikan antara pemahaman konsep matematika materi aritmatika sosial dengan hasil belajar IPS materi PPH, dimana $r_{\text {hitung }}$ sebesar 0.90 sedangkan $r$ table dengan $\mathrm{n}=30$ adalah 0.361 dengan taraf signifikan 0,05 .
\end{abstract}

Kata Kunci: pemahaman kosep, hasil belajar, aritmatika sosial dan IPS.

Mathematics is inseparable from abstract concepts, mastery of mathematical concepts is a prerequisite for being able to understand and develop other branches of science. Mathematics also has a connection between science and each other so that in introducing new concepts, a higher concept is needed. As a universal science, mathematics cannot be separated from various other disciplines. One of the sciences or subjects that has relevance to mathematics is Social Sciences (IPS). This study aims to determine whether there is a positive correlation between the understanding of the concept of social arithmetic with social studies learning outcomes in PPH material. The method used in this study is a quantitative descriptive method with survey techniques through a correlation approach. The population used in this study is class VIII students, amounting to 30 students. The data collection technique used was a multiple choice test with 30 items. The data analysis technique used to test the hypothesis is the product moment correlation technique. The results of this study indicate that there is a significant relationship between understanding mathematical concepts of social arithmetic material with social studies learning outcomes PPH material, where $r$ counts at 0.90 while $r$ table with $n=30$ is 0.361 with a significant level of 0.05 .

Keywords: understanding concepts, learning outcomes, social arithmetic and social studies.

\section{PENDAHULUAN}

Pendidikan merupakan kegiatan atau usaha yang dilakukan terhadapat anak yang dilakukan sejak dia dilahirkan untuk mencapai kedewasaan baik secara jasmani maupun rohaninya. Dalam pendidikan terdapat 3 aspek yang sangat penting yaitu aspek koqnitif, psikomotorik dan afektif. Ketiga aspek ini terdapat dalam proses pendidian. Pendidikan bertujuan untuk membantu manusia untuk mewujudkan manusia seutuhnya.
Pendidikan pada hakekatnya berlangsung dalam suatu proses. Proses itu berlangsung berupa transformasi tentang pengetahuan, teknologi dan ketrampilan. Penerima suatu proses pendidikan adalah anak atau siswa yang sedang tumbuh dan berkembang menuju ke pendewasaan kepribadian dan penguasaan pengetahuan. Selain itu dengan adanya pendidikan diharapkan dapat memahami potensi yang ada pada diri siswa sendiri. 
Dalam arti yang sederhana pendidikan diartikan sebagai usaha manusia untuk membina kepribadiaannya sesuai dengan sesuai dengan nilai-nilai di dalam masyarakat.

Matematika merupakan salah satu bidang studi yang ada pada semua jenjang pendidikan, mulai dari tingkat sekolah dasar hingga perguruan tinggi. Bahkan matematika diajarkan ditaman kanak-kanak secara informal. Kurang tanggapnya siswa terhadap pelajaran matematika akan berdampak pada pelajaran lain yang berkaitan dengan matematika, oleh karena itu ilmu matematika sangat penting dipelajari oleh para siswa untuk menunjang pelajaran lain. Secara tidak sadar matematika digunakan pada kehidupan sehari hari seperti menghitung uang dan sebagainya. Begitu juga dengan pelajaran lain yang membutuhkan dasar dari matematika seperti kimia fisika, ips, akuntansi dan masih banyak lagi.

Belajar matematika merupakan syarat cukup untuk melanjutkan pendidikan ke jenjang berikutnya. Karena dengan belajar matematika, kita akan belajar bernalar secara kritis, kreatif, dan aktif. Matematika merupakan ide-ide abstrak yang berisi simbol-simbol, maka konsep matematika harus dipahami terlebih dahulu. Bidang studi matematika merupakan salah satu komponen pendidikan dasar dalam bidang - bidang pengajaran. Bidang studi matematika ini diperlukan untuk proses perhitungan dan proses berpikir yang sangat dibutuhkan oleh setiap orang dalam menyelesaikan berbagai macam masalah.

Bidang studi matematika merupakan bidang studi yang berguna dalam menyelesaikan berbagai masalah dalam kehidupan sehari-hari yang berhubungan dengan hitung menghitung atau yang berkaitan dengan urusan angka-angka berbagai macam masalah, yang memerlukan suatu keterampilan dan kemampuan untuk memecahkannya.

Pemahaman konsep merupakan bagian penting dalam pembelajaran matematika. Dalam mempelajari matematika siswa harus memahami konsep matematika terlebih dahulu agar dapat menyelesaikan soal-soal dan mampu mengaplikasikan pembelajaran tersebut di dunia nyata. Siswa yang nantinya ikut andil dalam pengembangan matematika lebih lanjut ataupun dalam mengaplikasikan matematika dalam kehidupan seharihari.

Selain itu, dengan menghubungkan konsep-konsep matematika dengan kehidupan nyata akan membuat proses pembelajaran matematika akan menjadi lebih menarik, lebih nyata dan berguna. Dengan demikian, diharapkan dapat semakin menambah minat dan meningkatkan rasa keingintahuan siswa terhadap pelajaran matematika.

Oleh karena itu, wajar apabila pada tingkat materimateri pelajaran di sekolah pun konsep-konsep matematika melekat pada berbagai pelajaran, seperti pelajaran geografi, fisika, kimia, biologi, sosial bahkan pelajaran agama sehingga penguasaan konsep-konsep matematika merupakan prasyarat untuk dapat memahami dan mengembangkan cabang ilmu-ilmu yang lain. Kita tahu bahwa matematika juga memiliki hubungan antara yang satu dengan yang lain sehingga dalam setiap memperkenalkan konsep yang baru diperlukan konsep selanjutnya yang lebih tinggi

Sebagai ilmu yang universal, matematika tidak dapat terpisahkan dari berbagai disiplin ilmu lain. Salah satu ilmu atau matapelajaran yang memiliki keterkaitan dengan matematika salah satunya adalah Ilmu Pengetahuan Sosial (IPS). IPS merupakan matapelajaran yang mengkaji berbagai disiplin ilmu sosial serta kegiatan dasar manusia yang dikemas secara ilmiah.

Salah satu materi ajar yang terdapat dalam IPS yang membutuhkan pemahaman konsep matematika salah satunya adalah Pajak Penghasilan (PPh). Dalam menyelesaikan permasalah yang berkaitan dengan $\mathrm{PPh}$, konsep pendukung yang diperlukan adalah aritmatika sosial. Kita ketahui bahwa aritmatika sosial sangat berguna dalam menyelesaikan permasalah sehari - hari seperti untung rugi, suku bunga, potongan harga dan perhitungan pajak dan lain - lain. Oleh karena itu, sebelum siswa mempelajari materi $\mathrm{PPh}$ yang terdapat dalam matapelajaran IPS, diharapkan siswa sudah mampu memahami konsep aritmatika sosial.

Dengan demikian, apabila siswa memiliki pemahaman konsep aritmatika sosial yang baik diharapkan siswa dapat menyelesaikan permasalah mengenai $\mathrm{PPh}$ dapat diselesaikan secara maksimal. Maka dengan kerangka berpikir tersebut, mata pelajaran matematika dan IPS memiliki keterkaitan khusus dalam suatu pemecahan masalah khususnya dalam perhitungan $\mathrm{PPh}$ yang menggunakan konsep aritmatika sosial.

Hasil belajar merupakan tolak ukur yang digunakan untuk menentukan tingkat keberhasilan siswa dalam mengetahui dan memahami suatu mata pelajaran, biasanya dinyatakan dengan nilai yang berupa huruf atau angka-angka. Hasil belajar dapat berupa keterampilan, nilai dan sikap setelah siswa mengalami proses belajar. Melalui proses belajar mengajar diharapkan siswa memperoleh kepandaian dan kecakapan tertentu serta perubahan-perubahan pada dirinya.

Menurut Sudjana, hasil belajar adalah kemampuankemampuan yang dimiliki siswa setelah ia menerima pengalaman belajarnya (Nana Sudjana: 2010). Hasil peristiwa belajar dapat muncul dalam berbagai jenis perubahan atau pembuktian tingkah laku seseorang. Sedangkan menurut Purwanto, hasil belajar adalah nilai hasil-hasil pelajaran yang telah diberikan guru kepada murid-muridnya dalam jangka waktu tertentu (Ngalim Purwanto: 2009). Artinya setelah siswa melakukan 
kegiatan belajar dikelas, siswa akan mendapatkan nilai dari hasil materi pelajaran yang telah diberikan oleh guru.

Dari beberapa pendapat diatas dapat disimpulkan bahwa, hasil belajar merupakan perubahan tingkah laku yang menjadi tolak ukur atau patokan untuk menentukan tingkat keberhasilan siswa dalam mengetahui dan memahami suatu materi pelajaran dari proses pengalaman belajarnya.

Menurut Bloom, hasil belajar mencakup kemampuan kognitif, afektiff, dan psikomotorik. Domain kognitif adalah knowledge (pengetahuan, ingatan), comprehension (pemahaman, menjelaskan, meringkas, contoh), application (menerapkan), analysis (menguraikan, menentukan hubungan), synthesis (mengorganisasikan, merencanakan, membentuk bangunan baru), dan evaluation (menilai). Domain afektif adalah receiving (sikap menerima), responding (memberikan respon), valving (nilai), organization (organisasi), characterization (karaktnerisasi). Domain psikomotorik meliputi initiatory, pre-routine, dan rountinized. Psikomotorik juga mencakup keterampilan produktif, teknik, fisik, sosial, manajerial, dan intelektual (Agus Suprijono: 2011). Ilmu Pengetahuan Sosial adalah ilmu pengetahuan yang mengkaji berbagai disiplin ilmu sosial dan humoniora serta kegiatan dasar manusia yang dikemas secara ilmiah dalam rangka memberi wawasan dan pemahaman yang mendalam kepada peserta didik. Luasnya kajian IPS ini mencakup berbagai kehidupan sosial, ekonomi, psikologi, budaya, sejarah maupun politik, semuanya dipelajari dalam ilmu sosial ini (Ahmad Susanto: 2013). Dari beberapa pengertian IPS yang telah disebutkan, maka penulis dapat menyimpulkan bahwa IPS adalah suatu kajian ilmu terpadu dari ilmu- ilmu sosial dan ilmu - ilmu kemanusiaan serta kegiatan dasar manusia yang disajikan secara ilmiah yang meliputi sejarah, geografi, sosiologi, antropologi, politik serta ekonomi yang diorganisasikan untuk tujuan pembelajaran. Pada hakekatnya IPS merupakan ilmu yang mempelajari tentang semua aspek kehidupan dan interaksinya dalam masyarakat.

Hasil belajar IPS merupakan hasil optimal siswa baik dalam aspek koqnitif, efektif, ataupun psokomotorik yang diperoleh siswa setelah mempelajari IPS dengan jalan mencari berbagi informasi yang dibutuhkan baik berupa perubahan tingkah laku, pengertahuan, maupun keterampilan sehingga siswa tersebut mampu mencapi hasil maksimal balajarnya serta memecahkan masalah yang berkaitan dengan masalah sosial dan menerapkannya dalam kehidupan masyarakat.

Pajak merupakan sumber penghasilan negara yang berasal dari rakyat yang sangat penting. Perolehan pajak yang dari rakyat akan dikembalikan lagi kepada rakyat melalui pembangunan. Dalam pemungutan pajak, terdapat pihak - pihak (orang maupun badan) yang dikenakan pajak atau disebut juga sebagai Subjek pajak, sedangkan segala sesuatu yang akan dikenakan pajak disebut Objek Pajak. Penentuan dari Subjek pajak dan Objek pajak dilihat dari jenis pajak yang dipungut.

Pengertian pajak menurut Adriani Pajak adalah iuran wajib kepada negara (yang sifatnya dapat dipaksakan) berdasarkan Undang-Undang tanpa mendapat balas jasa secara langsung dan digunakan untuk membiayai pengeluaran-pengeluaran umum negara (K.Wardiyatmoko, 2012), sedangkan menurut Rachmat Sumitro, pajak adalah iuran rakyat kepada kas negara (peralihan kekayaan dari kas rakyat ke sektor pemerintah berdasarkan undang-undang) dapat dipaksakan dengan tidak mendapat jasa timbal (tegen prestasi) yang langsung dapat ditunjukkan dan digunakan untuk membiayai pengeluaran umum (Devi Puspitasari dan Agus Sugiantoro). Dari kedua pendapat tersebut diatas, maka penulis menarik kesimpulan bahwapajak adalah kewajiban setiap warga Negara yang berpenghasilan sesuai dengan aturan yang telah ditentukan, yang digunakan untuk membangun dan akan dinikmati hasil pembangunan tersebut oleh kita.

Pemahaman sebagai suatu kemampuan untuk mengetahui dan mengerti sesuatu secara mendalam, merupakan proses berpikir yang diperlukan manusia dalam kehidupan sehari-hari. Meningkatkan pemahaman siswa merupakan faktor yang sangat penting dalam pelaksanaan dan pembelajaran. Pembelajaran pada usia 12 tahun keatas, siswa berada pada periode formal. Pada periode ini siswa mampu berpikir logis dan matematis, abstrak dan bahkan mampu memahami hal-hal yang secara teoritik, mungkin terjadi akan tetapi belum dalam kenyataannya (Aunurrahman: 2008). Pemahaman merupakan kemampuan yang menuntut siswa untuk memahami atau mengerti tentang materi pelajaran yang disampaikan oleh guru (Zanial Arifin: 2009). Berdasarkan uraian diatas, penulis dapat menyimpulkan definisi pemahaman konsep adalah kemampuan yang dimiliki oleh siswa untuk menjelaskan kembali dan memahami konsep yang telah dipelajari sehingga siswa tersebut dapat mengembangkan kemampuan belajarnya sehingga siswa tidak hanya sekedar tahu atau mengingat sejumlah konsep yang dipelajari tetapi mampu mengungkapkan kembali dalam bentuk lain yang mudah dimengerti.

Dalam mempelajari tentang Pajak Penghasilan (PPh) diperlukan penyusunan tentang konsep aritmatika sosial. Hal ini berguna untuk membantu menyelesaikan soal-soal tentang PPh. Dengan begitu apa yang diharapkan oleh guru dan siswa akan tercapai dengan hasil yang memuaskan. 
Aritmatika sosial (variabel $\mathrm{x}$ ) merupakan salah satu materi ajar Matematika yang ada pada tingkat Sekolah Menengah Pertama (SMP)/MTs yang diajarkan dikelas VIII yang mempelajari pemecahan masalah dalam kehidupan sehari - hari seperti untung/rugi, potongan harga (diskon), suku bunga tunggal, dan perhitungan bruto, tara dan neto. Pajak Penghasilan (PPh) (variabel y) merupakan salah satu materi ajar yang terdapat dalam matapelajaran IPS yang diajarkan pada kelas VIII tingkat SMP. Didalamnya terdapat salah satu materi ajar yang membutuhkan konsep matematika dalam penyelesaiannya yaitu dengan menggunakan konsep aritmatika sosial.

\section{METODE}

Metode yang digunakan dalam penelitian ini adalah metode deskriptif kuantitatif dengan teknik survey melalui pendekatan korelasi. Teknik survey digunakan untuk mendapatkan data mengenai kedua variabel yang terdapat dalam penilitian ini yang selanjutnya diolah untuk diketahui apakah terdapat hubungan atau tidak antara kedua variable tersebut. Populasi adalah keseluruhan objek penelitian. Populasi target pada penelitian ini adalah seluruh siswa SMP Citra Mandala Bekasi, Populasi terjangkau adalah siswa kelas VIII SMP Citra Mandala Bekasi. Sampel adalah sebagian atau wakil populasi yang diteliti. Pengambilan sampel dilakukan secara acak dengan memilih satu kelas menggunakan random sampling dari kelas VIII yang tersedia. Teknik pengambilan sampel yang digunakan dalam penelitian ini adalah tenknik acak sederhana (simple random sampling). Pengambilan sampel dilakukan dengan mengambil 1 kelas dari beberapa kelas VIII yang ada untuk dijadikan kelas penelitian. Instrumen adalah alat pada waktu penelitian menggunakan sesuatu metode. Instrumen yang dugunakan pada penelitian ini adalah berupa tes pilihan ganda untuk Matematika sebanyak 30 soal, dan IPS sebanyak 30 soal. Tiap soal terdiri4 pilihan ganda yaitu a, b, c, d. Jawaban yang benar diberi skor 1 dan jawaban yang salah diberi skor 0. Instrumen ini mengukur aspek dengan kategori pengetahuan, pemahaman dan aplikasi. Sebelum soal digunakan sebagai instrumen pengumpul data, terlebih dahulu dilakukan uji coba Validasi dan Realiabilitas. Setelah melaksanakan uji instrument selanjutnya dilakukan uji prasyarat yaitu Uji Linieritas dan Uji Normalitas, dan selanjutnya melakukan uji Hipotesis dengan uji t.

\section{HASIL DAN PEMBAHASAN}

Dari Hasil instrumen penelitian penguasaan konsep aritmatika sosial (variabel $\mathrm{X}$ ) yang diujikan adalah 30 butir soal pilihan ganda, dengan 4 item pilihan yaitu A, B, C dan D. Setelah dilakukan uji validitas dengan bantuan vasilitas pada Ms Excel, maka 25 butir soal tersebut dinyatakan valid, Sedangkan 5 butir soal dinyatakan tidak valid yaitu butir 3,11,17,18 dan 28 .

Untuk instrumen penelitian pajak penghasilan pada materi IPS (variabel Y) yang diujikan adalah 30 butir soal pilihan ganda, dengan 4 item pilihan yaitu A, B, C dan D. Setelah dilakukan uji validitas dengan bantuan vasilitas pada Ms Excel, maka 25 butir soal tersebut dinyatakan valid, Sedangkan 5 butir soal dinyatakan tidak valid yaitu butir nomor 5,6,19,27 dan 28 .

Untuk hasil uji reliabilitas dari 25 butir soal variabel penguasaan konsep aritmatika $(\mathrm{X})$ didapat sebesar 0,855 dengan tingkat reliabilitas sangat tinggi Untuk instrumen pemahaman IPS materi pajak penghasilan (variabel Y), dengan jumlah butir soal yang sama, maka didapat hasil angka relabiltasnya adalah 0,878 .Berdasarkan data-data hasil uji tersebut, maka 25 butir soal variabel $X$ dan varibel $\mathrm{Y}$ dapat digunakan kembali untuk uji selanjutnya kepada 30 siswa sampel.

Berdasarakan nilai yang didapat dari hasil pembelajaran Aritmatika Sosial danIPS dalam materi pajak penghasilan terhadap 30 siswa sampel, setelah dilakukan verifikasi dan penyusunan data pemulis melakukan uji normalitas data dengan Uji Lilefors, maka didapat hasil sebagai beikut :

Untuk penguasaan konsep aritmatika sosial (variabel X) diperoleh nilai rata ratanya adalah 64.7 dan stándar deviasinya adalah $=11.61$. Dari perhitungan $\mathrm{L}_{\text {hitung }}=$ 0.123 sedang $\mathrm{L}_{\text {tabel }}=$ untuk $\mathrm{n}=30$ dengan tarif signifikansi 0.05 adalah $0.161 \mathrm{~L}_{\text {hitung }}<\mathrm{L}_{\text {tabel }}$ maka dapat disimpulkan data variabel $\mathrm{X}$ berdistribusi normal.

Untukpemahaman IPS materi pajak penghasilan (varibel Y) diperolehnilai rata-rata $=66,87$, stándar deviasi $=11,02$. Dari perhitungan $L_{\text {hitung }}=0.0935$ sedang $\mathrm{L}_{\text {tabel }}=$ untuk $\mathrm{n}=30$ dengan tarif signifikansi 0.05 adalah $0.161 \mathrm{~L}_{\text {hitung }}<\mathrm{L}_{\text {tabel }}$ maka dapat disimpulkan data variabel $\mathrm{X}$ berdistribusi normal.

Tabel 1. Hasil Uji Normalitas Data Varaiabel $\mathrm{X}$ dan Variabel Y

\begin{tabular}{lcccc}
\hline \multicolumn{1}{c}{ Variabel } & $\begin{array}{c}\text { Banyak } \\
\text { sampel }\end{array}$ & L hitung & L tabel & Ket \\
\hline $\begin{array}{l}\text { Pemahaman } \\
\text { Konsep }\end{array}$ & 30 & 0,123 & 0,161 & Normal \\
$\begin{array}{l}\text { Aritmetika } \\
\text { Sosial }\end{array}$ & & & & \\
\hline $\begin{array}{l}\text { Hasil Belajar } \\
\text { IPS materi Pajak } \\
\begin{array}{l}\text { Penghasilan } \\
\text { Sengal }\end{array}\end{array}$ & 30 & 0,0935 & 0,161 & Normal \\
& & & & \\
\hline
\end{tabular}


Uji lineritas data dilakukan dengan pendekatan anava, yaitu dengan menentukan jumlah kuadrat tengah ( JKT ) dan menetukan nilai $F_{\text {hitung }}$ untuk uji keberartian dan uji kelinnieran data. Dari hasil perhitungan pada lampiran diperoleh data sebagai berikut :

Tabel 2. Anava untuk Uji Keberartian dan Kelinieran Regresi

\begin{tabular}{|c|c|c|c|c|}
\hline $\begin{array}{l}\text { Sumber } \\
\text { Variasi }\end{array}$ & $\mathrm{dk}$ & $\begin{array}{c}\text { Jumlah } \\
\text { Kuadrat } \\
\text { (JK) }\end{array}$ & $\begin{array}{c}\text { Rerata } \\
\text { Jumlah } \\
\text { Kuadrat } \\
\text { (RJK) }\end{array}$ & $\frac{F_{\text {hitung }}}{F_{\text {tabel }}}$ \\
\hline Total (T) & 30 & 143264 & - & \multirow{3}{*}{$F_{h}=1,52$} \\
\hline Regresi (a) & 1 & 138720 & 138720 & \\
\hline Regresi (b) & 1 & 3709,28 & 3709,28 & \\
\hline Residu & 28 & 834,72 & 29,81 & \multirow{2}{*}{$\mathrm{F}_{\mathrm{t}}=2,43$} \\
\hline Tuna Cocok & 9 & 349,52 & 38,84 & \\
\hline Galat & 19 & 485,2 & 25,54 & $\mathrm{~F}_{\mathrm{h}}<\mathrm{F}_{\mathrm{t}}$ \\
\hline
\end{tabular}

Dari hasil uji keberartian regresi dipeoleh $\mathrm{F}_{\text {hitung }}<$ $F_{\text {tabel }}(1,52<2,43)$ pada taraf signifikan $\alpha=0.05$ dengan $n$ $=30 ; \mathrm{k}=10 ; \mathrm{dk}$ pembilang $=9 \mathrm{dan} \mathrm{dk}$ penyebut $=19$, maka hipotesis nol (Ho ) diterima yang berarti regresi linear artinya terdapat hubungan linear dari kedua variabel.

Selanjutnya hubungan linieritas variabel $\mathrm{X}$ dan variabel Y dapat divisualisasikan pada gambar di bawah ini:

Diketahui : Nilai $a=5,26$

Nilai $b=0,97$

$\ddot{\mathrm{Y}}=\mathrm{a}+\mathrm{bX}$

$\ddot{Y}=5,26+0,97 X$

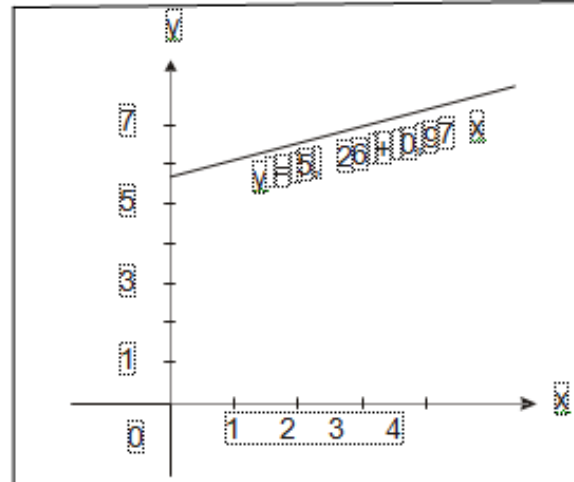

Gambar 1. Garis Linier Variabel X dengan Variabel Y

Untuk mengetahui seberapa besar kekuatan hubungan antara variabel $\mathrm{X}$ dan $\mathrm{Y}$ dalam penelitian ini penulis menggunakan tehnik analisis korelasi. Adapun tehnik análisis korelasi yang dipilih adalah korelasi Pearson Product Moment.

Analisis Korelasi Product Moment Tehnik análisis korelasi product moment adalah termasuk statistik paramoterik yang menggunakan data interval dan ratio persyaratan tertentu, yaitu data diambil secara acak dan berdistribusi normal dan data yang dibuhungkan berpola linear dan memiliki pasangan yang sama.

Untuk mengetahui seberapa jauh tingkatan kekuatan hubungan pemahaman penguasaaan konsep aritmatika sosial terhadap materi IPS dalam pelajaran Pajak penghasilan, maka perlu dicari angka indeks korelasi atau koefisien korelasi dengan menggunakan rumus korelasi product moment. Berdasarkan perhitungan angka indeks korelasi variabel $\mathrm{X}$ dan variabel $\mathrm{Y}$ diperoleh indeks korelasi $=0.90 . \quad r_{x y}$ atau $\mathrm{r}_{\text {hitung }}$ dikonsultasikan dengan $\mathrm{r}_{\text {tabe }}$ dengan taraf signifikansi 0,05 dengan jumlah responden $30(\mathrm{n}=30)$ adalah 0,361 , maka $\mathrm{r}_{\text {hitung }}$ lebih besar dari $\mathrm{r}_{\text {tabel }}$ yaitu $0,90>0,361$ dengan demikian Ho ditolak $\mathrm{Hi}$ diterima. Dengan kata lain aplikasi penguasaan konsep aritmatika social terhadap materi IPS pajak penghasilan memberikan hasil yang positif

Untuk mengetahui koefisien korelasi $(r)=0,78$ berarti atau tidak harus diuji melalui uji t. Dari hasil pengujian diperoleh $t_{\text {hitung }}=10.9$ sedangkan $t_{\text {tabel }}$ pada taraf signifikan 0.05 adalah 2,042. Maka dapat disimpulkan $t_{\text {hitung }}<\mathrm{t}_{\text {tabel }}(2,042)$ berarti koefisien korelasi signifikan. Dengan demikian dapat disimpulkan bahwa hasil aplikasi penguasaan konsep aritmatika social terhadap materi pajak penghasilan dalam pelajaran IPS memberikan kontribusi yang signifikan. Untuk menentukan kadar konstribusi variabel $\mathrm{X}$ terhadap variabel $\mathrm{Y}$ dapat dilakukan dengan cara mengalikan koefisen determinasi atau $\mathrm{r}^{2}$ dengan $100 \%$. Berdasarkan nilai koefisien korelasi $(r)=0,90$ diperoleh nilai koefisien determinasi $=81 \%$ hasil kontribusi pemahaman konsep aritmatika sosial, sedangkan sisanya $19 \%$ kontribusi faktor lain.

\section{PENUTUP}

\section{Simpulan}

S Berdasarkan hasil uji hipotesis dan pembahasan pada bab IV maka kesimpulan dari hasil penelitian adalah "Terdapat hubungan positif yang signifikan antara penguasaan konsep aritmatika sosial terhadap hasil belajar IPS pada materi pajak penghasilan di kelas VIII SMP Citra Mandala Bekasi tahun pelajaran 2016/2017”. Hal ini dapat dibuktikan oleh :

Kekuatan hubungan tersebut dapat dibuktikan oleh hasil uji korelasi $=0,90 . r_{x y}$ atau $\mathrm{r}_{\text {hitung }}$ dikonsultasikan dengan $r_{\text {tabel }}$ dengan taraf signifikan 0,05 dengan jumlah 
responden $30(\mathrm{n}=30)$ adalah 0,361 , maka $\mathrm{r}_{\text {hitung }}$ lebih besar dari $\mathrm{r}_{\text {tabel }}$ yaitu $0,90>0,361$ dengan demikian Ho ditolak Hi diterima. Artinya terdapat hubungan postif antara penguasaan konsep aritmatika sosial dengan hasil belajar IPS dalam materi pajak penghasilan (PPh).

Bila besarnya korelasi $(r)=0,78$ ditindak lanjuti dengan uji t keberartian maka didapat $r_{\text {hitung }}(10.9)>r_{\text {tabel }}$ $(2,042)$ berarti koefisien korelasi signifikan. Ini artinya korelasi tersebuty adalah signifikan.

Bila besarnya nilai korelasi $\mathrm{r}_{\text {hitung }}=0,90$ ditindaklanjuti dengan uji KD ( koefisien determinasi ) maka di dapat angka koefisien determiansi $\mathrm{KD}=81 \%$ ini berarti bahwa penguasaan konsep aritmatika sosial dapat memberikan kontribusi sebesar $81 \%$ terhadap hasil belajar IPS dalam materi pajak penghasilan. Dan sisanya 19\% kontribusi dari factor lain yang tidak diteliti.

\section{Saran}

Berdasarkan kesimpulan diatas, peneliti ingin memberikan saran agar keberhasilan proses belajar mengajar dapat tercapai dengan baik: (1)Guru diharapkan menguasai dan memiliki kemampuan profesional keguruan baik didalam kelas maupun diluar kelas, (2) Guru diharapkan didalam melaksanakan pembelajaran matematika, hendaknya lebih menjelaskan kemanfaatan matematika terhadap pelajaran lainnya, dengan banyak memberikan contoh aplikasi matematika terhadap mata pelajaran lainnya sehingga dapat memotavasi siswa untuk lebih giat mempelajari matematika. (3) Kepala Sekolah diharapkan dapat merekomendasikan kepada para guru matematika agar lebih mengakselerasikan pembelajaran matematika terhadap pelajaran IPS agar/siswa/dapat memahami materi pelajaran IPS yang membutuhkan aplikasi matematika

\section{DAFTAR PUSTAKA}

Aunurrahman. (2008) Belajar dan Pembelajaran. Bandung: Alfabeta.

Arifin , Zanial. (2009) Evaluasi Pembelajaran. Bandung: Remaja Rosdakarya

Kusuma, A. P., \& Khoirunnisa, A. (2018). Penerapan Model Pembelajaran Kooperatif Tipe Make a Match dan Team Games Tournament terhadap Hasil Belajar. NUMERICAL: Jurnal Matematika dan Pendidikan Matematika, 1-14.

Purwanto, Ngalim. (2008) Prinsip-prinsip dan Evaluasi Pengajaran. Bandung: Remaja Rosda Karya.

Rahmawati, N. K., \& Hanipah, I. R. (2018). Penerapan Model Pembelajaran Kooperatif Tipe Think Pair Share (TPS) Dan Model Pembelajaran Kooperatif Tipe Student Team Achievement Division (STAD) Terhadap Hasil Belajar Matematika Siswa Pada
Materi Garis Singgung Lingkaran. NUMERICAL: Jurnal Matematika dan Pendidikan Matematika, 99114.

Sudjana ,Nana. (2010). Penilaian Hasil Proses Belajar Mengajar. Bandung: Remaja Rosdakarya.

Suprijono ,Agus. (2011) Cooperative Learning Teori dan Aplikasi PAIKEM. Yogyakarta: Pustaka Pelajar. 2011.

Wardiyatmoko. K, (2012) Ilmu Pengetahuan Sosial kelas 2. Jakarta: Penerbit Erlangga. 